\title{
Importance Performance Analysis Kualitas Pelayanan Kesehatan Klien Rawat Jalan Peserta Jaminan Kesehatan Nasional
}

\section{Importance Performance Analysis of Health Service Quality on Jaminan Kesehatan Nasional Participants}

\author{
Putri Alawiyah $^{1}$, Dian Safriantini ${ }^{2}$ \\ Fakultas Kesehatan Masyarakat, Universitas Sriwijaya Palembang, Indonesia
}

\section{ARTICLE INFO}

\section{Article history:}

Received date

21 Dec 2019

Revised date

24 Apr 2020

Accepted date

26 Apr 2020

\section{Keywords:}

National Health Insurance; Performance analysis; Services quality.

\section{Kata kunci:}

Jaminan Kesehatan Nasional; Performance analysis; Kualitas pelayanan.

\begin{abstract}
ABSTRAK
Health care usually is focused on first-level health services (Puskesmas) to reduce the cost of health care covered by the BPJS Kesehatan. The quarterly visiting data of Jaminan Kesehatan Nasional (JKN) participants in the Inderalaya Puskesmas show a fluctuating trend. The objective of this study is to analyze the level of attribute towards the quality of health care service to the outpatient covered by JKN in the Inderalaya Puskesmas throughout 2018. This study employs a quantitative descriptive research method using Importance-Performance Analysis (IPA). The sample of this study were $122 \mathrm{JKN}$ participants chosen by accidental sampling in the site. Data gathering was conducted with the questionnaires of expectation and reality consisting of eight quality dimensions and 30 attributes of statements. The overall conformity level in this study is $94,16 \%$. The study found many respondents are dissatisfied with five care namely effectiveness $(93,14 \%)$, physical/direct evidence $(91,93 \%)$, reliability $(93,86 \%)$, responsiveness $(93,07 \%)$, and insurance $(93,24 \%)$. Results of the cartesian-diagram analysis suggest that from 30 attributes, there were four attributes in the A quadrant, 12 attributes in the B quadrant, 11 attributes in the C quadrant, and three attributes in the D quadrant.
\end{abstract}

\begin{abstract}
Pelayanan kesehatan difokuskan pada tingkat pertama (Puskesmas) untuk menurunkan beban biaya kesehatan yang dijamin oleh BPJS Kesehatan. Data kunjungan klien rawat jalan peserta JKN di Puskesmas Indralaya tiap catur wulan cenderung fluktuatif. Penelitian ini bertujuan untuk menganalisis tingkat kesesuaian atribut terhadap kualitas pelayanan kesehatan pada klien rawat jalan peserta JKN di Puskesmas Indralaya Tahun 2018. Desain penelitian deskriptif kuantitatif, dengan menggunakan analisis Importance Performance Analysis (IPA). Sampel dalam penelitian ini adalah klien rawat jalan peserta JKN berjumlah 122 orang yang terpilih dengan tehnik accidental sampling sesuai dengan kriteria pengambilan sampel (insklusi dan eksklusi). Pengumpulan data dilakukan dengan kuesioner harapan dan kenyataan masing-masing terdiri dari 8 dimensi kualitas pelayanan dengan 30 atribut pernyataan. Tingkat kesesuaian keseluruhan atribut pada penelitian ini yaitu sebesar $94,16 \%$. Hasil analisis menunjukkan sebagian besar responden belum merasa puas terhadap pelayanan yang diberikan pada 5 (lima) dimensi dari 8 dimensi yang ada yaitu dimensi efektivitas $(93,14 \%)$, bukti fisik/bukti langsung $(91,93 \%)$, reliabilitas $(93,86 \%)$, daya tanggap $(93,07 \%)$, dan jaminan $(93,24 \%)$. Berdasarkan analisis dengan diagram kartesius dapat disimpulkan bahwa dari 30 atribut, terdapat empat atribut di kuadran A, 12 atribut di Kuadran B, 11 atribut di kuadran C, dan tiga atribut di kuadran D.
\end{abstract}

Corresponding Author:

Dian Safriantini

Fakultas Kesehatan Masyarakat, Universitas Sriwijaya Palembang, Indonesia

Email: dian.safriantini@gmail.com/dian_safriantini@fkm.unsri.ac.id

\section{PENDAHULUAN}

Pusat kesehatan masyarakat atau dikenal dengan nama Puskesmas adalah fasilitas pelayanan kesehatan yang menyelenggarakan upaya kesehatan masyarakat dan upaya kesehatan perseorangan tingkat pertama, dengan lebih mengutamakan upaya promotif dan preventif, 
untuk mencapai derajat kesehatan masyarakat yang setinggi-tingginya di wilayah kerjanya (Permenkes RI, 2014). Pelayanan Kesehatan Jaminan Kesehatan Nasional (JKN) memfokuskan di Pelayanan Kesehatan Tingkat Pertama (FKTP), seperti di puskesmas. Dengan demikian kualitas fasilitas kesehatan primer ini harus dijaga, mengingat efek dari implementasi JKN kedepan, akan mengakibatkan naiknya permintaan (demand) masyarakat untuk mendapatkan pelayanan kesehatan.

Peningkatan kualitas pelayanan kesehatan bagi peserta JKN bertujuan agar pelayanan kesehatan tidak lagi terpusat di rumah sakit atau fasilitas kesehatan (faskes) tingkat lanjutan, tetapi pelayanan kesehatan harus dilakukan secara berjenjang sesuai dengan kebutuhan medis. Prinsip ini akan memberlakukan pelayanan kesehatan difokuskan di Pelayanan Kesehatan Tingkat Pertama (FKTP)/Fasilitas kesehatan Primer seperti di puskesmas yang akan menjadi gerbang utama peserta JKN dalam mengakses pelayanan kesehatan (BPJS Kesehatan, 2015)

Beberapa teori mengatakan bahwa, rendahnya penggunaan fasilitas kesehatan sering disebabkan oleh faktor jarak antara fasilitas tersebut dengan masyarakat yang terlalu jauh (baik jarak secara fisik maupun sosial), tarif yang tinggi, pelayanan yang tidak memuaskan dan sebagainya (Mamik, 2010). Menurut (Anggraheni, 2012) pendapatan keluarga, tingkat pendidikan, jarak dan kualitas layanan juga berpengaruh secara signifikan terhadap frekuensi kunjungan ke layanan kesehatan.

Penelitian yang dilakukan Ainy, Misnaniarti, \& Fajar (2012) mendapatkan ratarata tingkat kesesuaian antara kinerja dan harapan klien pada pelayanan jaminan sosial kesehatan di Puskesmas Swakelola Pembina Sumatera Selatan adalah $83,44 \%$. Pada setiap dimensi masih terdapat nilai kesesuaian di bawah nilai rata-rata (belum puas), yaitu pada dimensi reliability $(81,61 \%)$, dan dimensi tangible $(83,11 \%) .10$ Begitu juga dengan penelitian yang dilakukan oleh (Emilia, 2016) bahwa kualitas pelayanan kesehatan di UPT Puskesmas Sindangjawa secara umum dapat dikatakan belum memuaskan klien dengan skor gap -0,154. Pada penelitian ini terdapat beberapa dimensi yang belum memuaskan klien yaitu dimensi reliability ($0,288)$, dimensi responsiveness $(-0,240)$, dan dimensi empathy $(-0,309)$.

Puskesmas Indralaya merupakan salah satu Puskesmas terakreditasi di Kabupaten Ogan Ilir dengan jumlah penduduk yang paling banyak dari seluruh Puskesmas di wilayah kerja Dinas Kesehatan Kabupaten Ogan Ilir Tahun 2017 yaitu sebanyak 32.474 orang (Dinas Kependudukan dan Pencatatan Sipil Kabupaten Ogan Ilir, 2018) Sedangkan jumlah kepesertaan Jaminan Kesehatan Nasional di Puskesmas Indralaya tahun 2017 yaitu sebanyak 13.814 orang atau $42,54 \%$ dari jumlah seluruh penduduk. Kemudian jumlah kunjungan peserta Jaminan Kesehatan Nasional di Puskesmas Indralaya tahun 2017 sebanyak 8.711 orang atau $63,06 \%$ dari jumlah seluruh peserta JKN (BPJS Kesehatan KC Palembang, 2018). Berdasarkan data dari laporan JKN di Puskesmas Indralaya Tahun 2017 didapatkan bahwa data percatur wulan menunjukkan kunjungan klien rawat jalan peserta JKN cenderung fluktuatif, yaitu pada periode bulan Januari-Maret 2017 adalah 2.591 orang, pada April-Juni 2017 adalah 1.537 orang, pada Juli-September 2017 adalah 2.733 orang, dan Oktober-Desember 2017 adalah 2.396 orang (Puskesmas Indralaya, 2018). Tujuan penelitian untuk menganalisis tingkat kesesuaian atribut terhadap kualitas pelayanan kesehatan pada klien rawat jalan peserta JKN dengan Importance Performance Analysis (IPA) di Puskesmas Indralaya.

\section{METODE}

Penelitian ini merupakan penelitian analitik dengan pendekatan cross sectional, yang dilakukan dari bulan Maret sampai bulan April 2018 di Puskesmas Indralaya Kabupaten Ogan Ilir. Sampel pada penelitian adalah klien rawat jalan peserta JKN yang sebelumnya pernah berkunjung ke Puskesmas Indralaya, sedang berada dilokasi penelitian, dan bersedia menjadi responden. Sampel berjumlah 122 responden yang diambil dengan menggunakan tehnik accidental sampling.

Uji validitas dilakukan terhadap 30 orang yang sudah merasakan pelayanan kesehatan di Puskesmas Tanjung Raja Ogan Ilir. Puskesmas ini memiliki karakteristik yang sama dengan tempat penelitian yaitu jumlah peserta JKN terbanyak kedua dan berada di daerah pasar dan dekat jalan raya.

Pengumpulan data dilakukan dengan kuesioner harapan dan kenyataan masing-masing terdiri dari 8 dimensi kualitas pelayanan dengan 30 atribut pernyataan. Analisis data pada penelitian ini yaitu dengan analisa statistik deskriptif (menggambarakan karakteristik responden penelitian) dan menggunakan analisis dengan Importance Performance Analysis (IPA).

Penelitian ini telah melewati kaji etik dan memperoleh Sertifikat Persetujuan Etik dengan 
Nomor 86/UN9.1.10/KKE/2018 oleh Komisi Etik Penelitian Kesehatan (KEPK) Fakultas Kesehatan Masyarakat, Universitas Sriwijaya.

\section{HASIL}

Tabel 1. Persentase Karakteristik Responden

\begin{tabular}{lrr}
\hline Karakteristik Responden & f & \% \\
\hline Jenis Kelamin & & \\
Laki-laki & 39 & 31.97 \\
Perempuan & 83 & 68.03 \\
\hline Umur & & \\
$7-27$ & 12 & 9.84 \\
$28-37$ & 23 & 18.86 \\
$38-47$ & 21 & 17.21 \\
$48-57$ & 29 & 23.77 \\
$\geq 58$ & 37 & 30.32 \\
\hline Pekerjaan & & \\
Tidak bekerja & 58 & 47.55 \\
Petani/Buruh & 21 & 17.21 \\
Pegawai swasta/wiraswasta & 16 & 13.11 \\
PNS/TNI/POLRI & 16 & 13.11 \\
Pelajar/Mahasiswa & 4 & 3.28 \\
Lain-lain & 7 & 5.74 \\
\hline Pendidikan & & \\
Tidak sekolah & 2 & 1.64 \\
SD & 42 & 34.43 \\
SMP & 21 & 17.21 \\
SMA & 40 & 32.79 \\
D1,D2,D3,D4 & 3 & 2.46 \\
S1,S2,S3 & 14 & 11.47 \\
\hline Status Kepesertaan & & \\
PBI & 76 & 62.30 \\
Non PBI & 46 & 37.70 \\
\hline
\end{tabular}

Berdasarkan tabel 1, responden pada penelitian ini sebagian besar adalah perempuan $(68,03 \%)$ dengan kelompok umur terbanyak adalah dikelompok umur di atas 58 tahun $(30,32 \%)$. Karena kebanyakan responden adalah perempuan dan di atas 58 tahun, status pekerjaan responden adalah sebagian besar tidak bekerja. Status pendidikan responden paling besar adalah tamatan Sekolah Dasar (SD) sebesar 34,43\%. Selain itu, sebagian besar responden adalah golongan PBI yaitu sebanyak 62,30\% dari total 122 responden.

\section{Analisis Kesesuaian Pelayanan Klien JKN}

Tingkat kesesuaian kenyataan (kinerja) dan harapan (kepentingan) klien rawat jalan peserta JKN yang diterima selama berobat di Puskesmas Indralaya diperoleh dari perhitungan skor menggunakan Importance Performance Analysis, yaitu analisis kesesuaian antara kinerja pelayanan dan harapan klien serta analisis kuadran. Harapan dan Kenyataan dapat membentuk kepuasan karena kepuasan merupakan kesesuaian antara kenyataan pelayanan yang diterima dengan harapan yang diinginkan.

\section{Dimensi Akses Pelayanan dan Bukti Fisik/Bukti Langsung}

Berikut ini merupakan distribusi tingkat kesesuaian harapan (kepentingan) dan kenyataan (kinerja) responden pada pelayanan kesehatan di Puskesmas Indralaya pada 8 dimensi yang ditanyakan. 
Tabel 2. Distribusi Tingkat Kesesuaian Harapan (Kepentingan) dan Kenyataan (Kinerja) Responden pada 8 Dimensi

\begin{tabular}{|c|c|c|c|c|c|c|}
\hline Atribut & $\mathbf{X i}$ & $\mathbf{Y i}$ & $\mathbf{X}$ & $\overline{\mathbf{Y}}$ & $\begin{array}{c}\text { Tingkat } \\
\text { Kesesuaian }(\%)\end{array}$ & $\begin{array}{c}\text { Kriteria } \\
\text { Kesesuaian }\end{array}$ \\
\hline \multicolumn{7}{|l|}{ A. Akses pelayanan } \\
\hline 1. Letak Puskesmas di pinggir jalan raya & 553 & 560 & 4.53 & 4.59 & 98.75 & M \\
\hline 2. Transportasi untuk menjangkau yankes & 542 & 555 & 4.44 & 4.55 & 97.66 & $\mathrm{BM}$ \\
\hline 3. Biaya yang terjangkau untuk mengakses yankes & 541 & 549 & 4.43 & 4.50 & 98.54 & $\mathrm{M}$ \\
\hline Rata-Rata & & & & & 98.32 & $\mathbf{M}$ \\
\hline \multicolumn{7}{|l|}{ B. Bukti Fisik/Bukti Langsung } \\
\hline 4. Pelayanan dokter, perawat, bidan, dsb sopan \& ramah & 500 & 531 & 4.10 & 4.35 & 94.16 & M \\
\hline 5. Kebersihan, kerapihan dan kenyamanan ruangan. & 487 & 531 & 3.99 & 4.35 & 91.71 & $\mathrm{BM}$ \\
\hline 6. Kelengkapan, kesiapan alat pemeriksaan yg dipakai. & 459 & 537 & 3.76 & 4.40 & 85.47 & $\mathrm{BM}$ \\
\hline $\begin{array}{l}\text { 7. Kebersihan perlengkapan di Puskesmas (Kursi, } \\
\text { meja,tempat tidur, dll) }\end{array}$ & 494 & 537 & 4.05 & 4.40 & 91.99 & $\mathrm{M}$ \\
\hline 8. Papan petunjuk arah yang jelas. & 545 & 566 & 4.47 & 4.64 & 96.29 & M \\
\hline Rata-Rata & & & & & 91.93 & BM \\
\hline \multicolumn{7}{|l|}{ C. Efisiensi } \\
\hline $\begin{array}{l}\text { 9. Dokter, perawat, bidan dan sebagainya memahami } \\
\text { tugas dan fungsinya masing-masing }\end{array}$ & 496 & 530 & 4.07 & 4.34 & 93.58 & BM \\
\hline 10. Waktu tunggu klien untuk mendaftar yang teratur & 506 & 535 & 4.15 & 4.39 & 94.58 & $\mathrm{BM}$ \\
\hline 11. Waktu Layanan & 479 & 509 & 9.93 & 4.17 & 94.11 & $\mathrm{BM}$ \\
\hline 12. Biaya kesehatan atau iuran murah & 531 & 544 & 4.35 & 4.46 & 97.61 & $\mathrm{M}$ \\
\hline Rata-Rata & & & & & 94.97 & $\mathbf{M}$ \\
\hline \multicolumn{7}{|l|}{ D. Efektivitas } \\
\hline 13. Pelayanan dokter, perawat, bidan, dsb cepat \& tepat & 502 & 535 & 4.11 & 4.39 & 93.83 & $\mathrm{M}$ \\
\hline $\begin{array}{l}\text { 14. Jumlah dokter, perawat, bidan, dsb cukup dalam } \\
\text { memberikan pelayanan pada klien }\end{array}$ & 472 & 514 & 3.87 & 4.21 & 91.83 & $\mathrm{BM}$ \\
\hline $\begin{array}{l}\text { 15. Pengobatan yang dianjurkan dokter, perawat, bidan, } \\
\text { dan sebagainya kepada klien merupakan teknologi } \\
\text { yang paling tepat pada situasi di Puskesmas }\end{array}$ & 481 & 513 & 3.94 & 4.20 & 93.76 & M \\
\hline Rata-Rata & & & & & 93.14 & BM \\
\hline \multicolumn{7}{|l|}{ E. Reliabilitas } \\
\hline 16. Prosedur penerimaan klien yang cepat dan tepat. & 495 & 520 & 4.06 & 4.26 & 95.19 & $\mathrm{M}$ \\
\hline $\begin{array}{l}\text { 17. Pelayanan pemeriksaan diagnosis dan perawatan } \\
\text { terhadap klien cepat dan tepat. }\end{array}$ & 485 & 520 & 3.98 & 4.26 & 93.27 & $\mathrm{BM}$ \\
\hline 18. Prosedur pelayanan kesehatan tidak berbelit-belit. & 500 & 537 & 4.10 & 4.40 & 93.11 & $\mathrm{BM}$ \\
\hline Rata-Rata & & & & & 93.86 & BM \\
\hline \multicolumn{7}{|l|}{ F. Daya Tanggap } \\
\hline $\begin{array}{l}\text { 19. Kemampuan dokter, perawat, bidan cepat tanggap } \\
\text { menyelesaikan keluhan klien. }\end{array}$ & 489 & 522 & 4.01 & 4.28 & 93.68 & M \\
\hline $\begin{array}{l}\text { 20. Dokter, perawat, bidan, dan sebagainya memberikan } \\
\text { informasi yang jelas kepada klien }\end{array}$ & 506 & 534 & 4.15 & 4.38 & 94.76 & M \\
\hline 21. Selalu ada dokter yang bertugas 24 jam & 473 & 526 & 3.88 & 4.31 & 89.92 & $\mathrm{BM}$ \\
\hline 22. Tindakan cepat saat klien membutuhkan pelayanan. & 496 & 528 & 4.07 & 4.33 & 93.94 & $\mathrm{M}$ \\
\hline \multicolumn{7}{|l|}{ G. Jaminan } \\
\hline $\begin{array}{l}\text { 23. Dokter, perawat, bidan, dan sebagainya mampu } \\
\text { menjaga kerahasiaan diagnosa penyakit klien. }\end{array}$ & 498 & 529 & 4.08 & 4.34 & 94.14 & M \\
\hline $\begin{array}{l}\text { 24. Pelayanan dokter, perawat, bidan dan sebagainya } \\
\text { menimbulkan rasa aman dan percaya }\end{array}$ & 516 & 540 & 4.23 & 4.43 & 95.56 & M \\
\hline $\begin{array}{l}\text { 25. Dokter, perawat, bidan, dan sebagainya mencuci } \\
\text { tangan sebelum dan sesudah melakukan tindakan }\end{array}$ & 485 & 540 & 3.98 & 4.43 & 89.81 & $\mathrm{BM}$ \\
\hline $\begin{array}{l}\text { 26. Dokter mengidentifikasi (menanyakan nama) klien } \\
\text { dengan benar sebelum tindakan }\end{array}$ & 527 & 564 & 4.32 & 4.62 & 93.44 & M \\
\hline Rata-Rata & & & & & 93.24 & $\mathbf{B M}$ \\
\hline \multicolumn{7}{|l|}{ H. Empati } \\
\hline $\begin{array}{l}\text { 27. Dokter, perawat, bidan, dan sebagainya } \\
\text { mendengarkan/menanggapi keluhan klien }\end{array}$ & 503 & 526 & 4.12 & 4.31 & 95.63 & M \\
\hline $\begin{array}{l}\text { 28. Pelayanan kepada semua klien tanpa memandang } \\
\text { status sosial (status kepesertaan JKN) dan lain-lain. }\end{array}$ & 509 & 542 & 4.17 & 4.44 & 93.91 & $\mathrm{BM}$ \\
\hline $\begin{array}{l}\text { 29. Antara dokter, perawat dan petugas lainnya dan } \\
\text { klien terjalin komunikasi yang baik. }\end{array}$ & 508 & 538 & 4.16 & 4.41 & 94.42 & $\mathrm{BM}$ \\
\hline $\begin{array}{l}\text { 30. Dokter, perawat, bidan, dan sebagainya memberikan } \\
\text { dorongan (mendoakan) pada kesembuhan klien }\end{array}$ & 516 & 542 & 4.23 & 4.44 & 95.20 & M \\
\hline Rata-Rata & & & & & 94.79 & $\mathbf{M}$ \\
\hline
\end{tabular}


Berdasarkan tabel 2, didapatkan informasi tentang total skor dan nilai rata-rata kenyataan dan harapan, serta tingkat dan kriteria kesesuaian setiap atribut dan setiap dimensi. Rata-rata tingkat kesesuaian pada dimensi akses pelayanan yaitu sebesar 98,32\%. Dengan demikian, dapat ditentukan kriteria kesesuaian pada dimensi ini yaitu sudah dapat dikatakan memuaskan klien rawat jalan peserta JKN di Puskesmas Indralaya. Kemudian pada dimensi ini terdapat satu dari tiga atribut yang belum memuaskan klien yaitu transportasi untuk menjangkau pelayanan kesehatan $(97,66 \%)$

Rata-rata tingkat kesesuaian pada dimensi bukti fisik/bukti langsung yaitu sebesar 91,93\%. Kemudian pada dimensi ini terdapat dua dari lima atribut yang belum memuaskan klien yaitu kebersihan, kerapihan, dan kenyamanan ruangan $(91,71 \%)$ dan kelengkapan dan kesiapan alat-alat pemeriksaan yang dipakai $(85,47 \%)$.

Selanjutnya, rata-rata tingkat kesesuaian pada dimensi efisiensi adalah sebesar 94,97\%. Terdapat tiga dari empat atribut yang belum memuaskan klien yaitu dokter, perawat, bidan dan sebagainya memahami tugas dan fungsinya masing-masing (93,58\%), waktu tunggu klien untuk registrasi/mendaftar yang teratur $(94,58 \%)$, dan waktu layanan $(94,11 \%)$.

Rata-rata tingkat kesesuaian pada dimensi efektivitas yaitu sebesar $93,14 \%$. Terdapat satu dari tiga atribut yang belum memuaskan klien yaitu jumlah dokter, perawat, bidan, dan sebagainya cukup dalam memberikan pelayanan pada klien $(91,83 \%)$.

Rata-rata tingkat kesesuaian pada dimensi reliabilitas yaitu sebesar $93,86 \%$. Terdapat dua dari tiga atribut yang belum memuaskan klien yaitu pelayanan pemeriksaan diagnosis dan perawatan terhadap klien cepatdan tepat $(93,27 \%)$ dan prosedur pelayanan kesehatan tidak berbelit-belit $(93,11 \%)$.

Rata-rata tingkat kesesuaian pada dimensi daya tanggap yaitu sebesar $93.07 \%$. Terdapat satu dari empat atribut yang belum memuaskan klien yaitu selalu ada dokter yang bertugas 24 jam $(89.92 \%)$.

Kemundian pada dimensi jaminan, ratarata tingkat kesesuaian adalah 93,24\%. Terdapat satu dari empat atribut yang belum memuaskan klien yaitu dokter, perawat, bidan, dan sebagainya mencuci tangan sebelum dan sesudah melakukan tindakan $(89.81 \%)$.

Rata-rata tingkat kesesuaian pada dimensi empati sebesar 94,79\%. Terdapat dua dari empat atribut yang belum memuaskan klien yaitu pelayanan kepada semua klien tanpa memandang status sosial (status kepesertaan JKN) dan lain- lain $(93,91 \%)$ dan antara dokter, perawat dan petugas lainnya dan klien terjalin komunikasi yang baik $(94,42 \%)$.

\section{Rata-Rata Tingkat Kesesuaian Atribut Berdasarkan Persepsi Klien}

Tabel 3. Rata-Rata Tingkat Kesesuaian Atribut Berdasarkan Persepsi Klien Tingkat

Dimensi Kualitas Pelayanan Kesesuaian (\%)

\begin{tabular}{lr} 
Akses Pelayanan & 98,32 \\
Bukti Fisik/Bukti Langsung & 91,93 \\
Efisiensi & 94,97 \\
Efektivitas & 93,14 \\
Reliabilitas & 93,86 \\
Daya Tanggap & 93,07 \\
Jaminan & 93,24 \\
Empati & 94,79 \\
\hline Jumlah Skor Keseluruhan & $\mathbf{2 0 0 , 4 9}$ \\
\hline Rata-rata Tingkat Kesesuaian & $\mathbf{9 4 , 1 6}$ \\
Atribut berdasarkan Persepsi Klien & $\mathbf{4 , 1 2}$ \\
\hline Rata-Rata $(\overline{\boldsymbol{X}})$ & $\mathbf{4 , 3 9}$ \\
\hline Rata-Rata $(\overline{\boldsymbol{Y}})$ &
\end{tabular}

Keterangan:

$\overline{\bar{X}}=$ Bobot rata-rata tingkat penilaian kenyataan

$\overline{\bar{Y}}=$ Bobot rata-rata tingkat penilaian harapan

Berdasarkan tabel 6, didapatkan informasi tentang tingkat kesesuaian setiap dimensi, jumlah skor keseluruhan, rata-rata tingkat kesesuaian atribut (tingkat kesesuaian secara keseluruhan) dan rata-rata ( $X$ dan $Y$ ). Adapun rata-rata tingkat kesesuaian secara keseluruhan yaitu sebesar 94,16\%.terdapat 3 dimensi yang memiliki tingkat kesesuaian $\geq$ tingkat kesesuaian keseluruhan yaitu dimensi akses pelayanan (98,32\%), efisiensi $(94,97 \%)$, dan empati $(94,79)$. Dimensi tersebut dapat dikatakan sudah memuaskan klien. Sedangkan terdapat lima dimensi yang memiliki tingkat kesesuaian $\leq$ tingkat kesesuaian keseluruhan yaitu dimensi efektivitas (93,14\%), bukti fisik/bukti langsung $(91,93 \%)$, reliabilitas $(93,86 \%)$, daya tanggap $(93,07 \%)$, dan jaminan $(93,24 \%)$ sehingga dapat dikatakan belum memuaskan klien. Kemudian dari tabel tersebut juga diketahui bobot rata-rata tingkat penilaian kenyataan $(4,12)$, nilai ini memotong tegak lurus pada sumbu horizontal, yakni sumbu yang mencerminkan kenyataan (X), serta diketahui bobot rata-rata tingkat penilaian harapan $(4,39)$, nilai ini memotong tegak lurus pada sumbu vertikal, yakni sumbu yang mencerminkan harapan (Y). 


\section{Diagram Kartesius Pelayanan Kesehatan Peserta JKN di Puskesmas Indralaya}

Untuk mengetahui strategi peningkatan kualitas pelayanan kesehatan terhadap klien peserta JKN, maka dilakukanlah analisis melalui diagram kartesius. Sebelum membuat diagram kartesius, maka dilakukan penentuan sumbu $\mathrm{X}$ dan sumbu Y dan koordinat setiap atribut melalui perhitungan rataan. Sumbu $X$ diagram kartesius didapatkan dari rata-rata skor tingkat kinerja (Kenyataan). Sumbu Y diagram kartesius didapatkan dari rata-rata skor tingkat kepentingan (harapan). Kemudian dibuat diagram kartesius menggunakan aplikasi komputer.

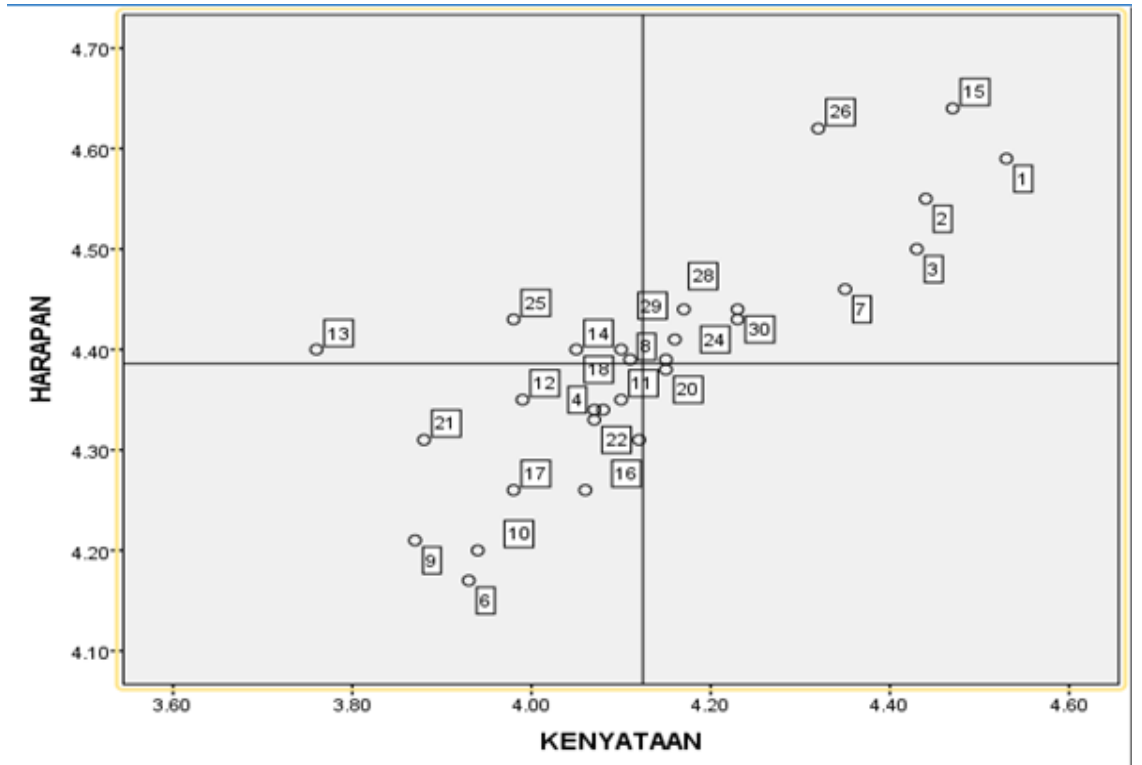

\section{Gambar 2. Diagram Kartesius Pelayanan Kesehatan Klien Rawat Jalan Peserta JKN di Puskesmas Indralaya}

Dari gambar 2, terlihat bahwa letak atribut pernyataan atau atribut yang mempengaruhi kepuasan klien peserta JKN terhadap pelayanan kesehatan di Puskesmas Indralaya tahun 2018 tersebar menjadi 4 kuadran, yaitu kuadran A terdapat 4 atribut dan menjadi prioritas utama, kemudian pada kuadran B terdapat 12 atribut, dan pada kuadran $\mathrm{C}$ terdapat 11 atribut, serta pada kuadran D terdapat 3 atribut.

Kuadran A (prioritas utama) menunjukkan faktor atau atribut yang dianggap mempengaruhi kepuasan pelanggan, termasuk unsur-unsur jasa yang dianggap sangat penting, namun manajemen belum melaksanakannya sesuai keinginan pelanggan. Adapun empat atribut yang di kuadran A tersebut adalah:

1. Atribut nomor 8 , yaitu harapan klien tinggi terhadap pelayanan yang cepat dan tepat oleh Dokter, Perawat, Bidan, dan sebagainya, tetapi pada kenyataannya dari hasil penelitian pada atribut ini masih rendah. Sehingga pada atribut ini klien belum merasakan puas.

2. Atribut nomor 13, yaitu harapan klien tinggi terhadap kelengkapan dan kesiapan alat-alat pemeriksaan yang dipakai, tetapi kenyataannya klien merasa kelengkapan dan kesiapan alat-alat pemeriksaan di Puskesmas ini masih kurang.
3. Atribut nomor 14, yaitu harapan klien terhadap kebersihan perlengkapan di Puskesmas (Kursi, meja, tempat tidur, dll) tinggi, tetapi kenyataannya klien merasa kebersihan kursi, meja, tempat tidur, dan lain-lain di Puskesmas masih rendah.

4. Atribut nomor 18, yaitu pada atribut ini harapan klien tinggi terhadap prosedur pelayanan kesehatan yang tidak berbelitbelit, tetapi pada kenyataannya klien merasa prosedur pelayanan kesehatan di Puskesmas ini berbelit-belit. Sehingga klien merasa belum puas.

\section{PEMBAHASAN}

Tingkat kesesuaian kenyataan dan harapan klien terhadap kualitas pelayanan kesehatan yang diterima klien JKN selama berobat di Puskesmas Indralaya pada penelitian ini dengan nilai ratarata seluruh dimensi adalah $94,16 \%$. Dalam hal ini pada setiap dimensi masih terdapat nilai kesesuaian dibawah nilai rata-rata. Hasil penelitian ini sejalan dengan penelitian yang dilakukan oleh (Sondari, 2015) dalam penelitiannya didapatkan rata-rata tingkat kesesuaian kepuasan klien menggunakan metode 
importance performance analysis yaitu sebesar 91,3\% yang terdiri dari 5 dimensi kualitas pelayanan. Dalam penelitiannya diketahui dari 5 dimensi kualitas pelayanan kesehatan tersebut terdapat 2 dimensi yang masih di bawah nilai rata-rata yaitu dimensi reliability $88,8 \%$ dan tangible $90,1 \%$.

\section{Dimensi Akses Pelayanan}

Akses atau keterjangkauan terhadap pelayanan yaitu pelayanan kesehatan dapat dengan mudah dicari oleh masyarakat, tidak terhalang oleh keadaan geografis, sosial, budaya, ekonomi, organisasi, ataupun bahasa (Pohan, 2007). Hasil penelitian menunjukkan bahwa tingkat kesesuaian pada dimensi akses pelayanan yaitu sebesar 98,32\% (>94,16\%), hal ini berarti dimensi akses pelayanan dapat disimpulkan memuaskan klien rawat jalan peserta JKN di Puskesmas Indralaya. Penelitian ini sejalan dengan penelitian yang dilakukan oleh (Jahid, Balqis, \& Hamzah, 2013) yang mendapatkan hasil sebanyak $98(98 \%)$ responden menyatakan akses keterjangkauan mudah diakses, dan dari 98 orang tersebut sebanyak 95 responden $(96,9 \%)$ menyatakan puas.

Secara letak geografis, Puskesmas Indralaya berlokasi di pinggir jalan raya dan di daerah pasar. Hal ini sejalan dengan (Bustami, 2011) bahwa akses pelayanan dikatakan memuaskan jika pada akses geografi mudah dijangkau masyarakat yaitu dapat diukur dengan jenis alat transportasi, jarak, dan waktu perjalanan. Berdasarkan tingkat kesesuaian pada penelitian ini letak Puskesmas Indralaya dapat dikatakan memuaskan klien yaitu sebesar $98,75 \%$ akan tetapi transportasi untuk menjangkau pelayanan kesehatan ini tingkat kesesuaiannya belum memuaskan klien yaitu sebesar 97,66\% karena sebagian besar responden menyatakan bahwa tempat tinggal responden jauh dari puskesmas sehingga memerlukan biaya transportasi yang lumayan mahal dengan menggunakan dua kali angkutan umum. Hasil penelitian juga menunjukkan bahwa klien merasa puas terhadap biaya untuk mengakses pelayanan kesehatan atau menuju Puskesmas Indralaya yang terjangkau yaitu sebesar $98,54 \%$. Hal ini sejalan dengan (Bustami, 2011) bahwa akses ekonomi berkaitan dengan kemampuan yang pembiayaannya terjangkau oleh pelanggan.

\section{Dimensi Bukti Fisik/Bukti Langsung}

Suatu pelayanan kesehatan memiliki bukti fisik yang baik apabila kondisi interior dan eksterior ruangan ditata secara menarik, kondisi kenyamanan dan kebersihan gedung, kerapihan dan kebersihan gedung, kerapihan dan kebersihan petugas, dan kecanggihan peralatan yang ada (Supranto, 2011). Hasil penelitian menunjukkan bahwa tingkat kesesuaian pada dimensi bukti fisik/bukti langsung yaitu sebesar 91,93\% $(<94,16 \%)$, sehingga dapat disimpulkan bahwa dimensi bukti fisik/bukti langsung belum memuaskan klien rawat jalan peserta JKN di Puskesmas Indralaya. Hal ini sejalan dengan penelitian yang dilakukan oleh (Sondari, 2015) dalam penelitiannya didapatkan bahwa dimensi bukti fisik/bukti langsung belum memuaskan klien, berdasarkan hasil penelitian yang dilakukannya dengan metode importance performance analysis diperoleh tingkat kesesuaian pada dimensi bukti fisik/bukti langsung yaitu sebesar $90,1 \%(<91,3 \%)$, dengan demikian disimpulkan bahwa dimensi bukti fisik/bukti langsung belum memuaskan klien.

Kepuasan klien JKN terhadap dimensi bukti fisik/bukti langsung harus ditingkatkan karena bukti fisik/bukti langsung yang baik menyebabkan harapan klien terhadap pelayanan menjadi tinggi. Hal ini berkaitan dengan pernyataan (Perwani, 2006) hal yang penting dalam housekeeping dan berkaitan erat dengan mutu produk/jasa adalah bagaimana institusi penyedia pelayanan mampu menghadirkan keindahan, kerapihan, kebersihan, dan kelengkapan dan kesehatan terhadap produk jasa yang ditawarkan kepada pelanggan. Penelitian yang dilakukan oleh (Basri \& Leoganda, 2016) mendapatkan hasil hubungan fasilitas ruang rawat inap dengan tingkat kepuasan klien BPJS adalah $p$-value $=0,034$, dengan derajat korelasi hubungan $r=0,426$ yang artinya mempunya korelasi kuat. Semakin baik fasilitas ruang rawat inap maka akan berdampak pada peningkatan kepuasan klien. Klien merasa puas ketika di rawat di rumah sakit akan merekomendasikan ke orang lain atau keluarga tentang kelengkapan fasilitas yang dimiliki setiap ruangan yang ada di rumah sakit dan ini sekaligus dapat menjadi promosi tersendiri untuk perkembangan rumah sakit kedepannya.

\section{Dimensi Efisiensi}

Efisiensi merupakan dimensi yang penting dari kualitas karena efisiensi akan mempengaruhi hasil pelayanan kesehatan, terutama sumber daya kesehatan yang terbatas, efisiensi merujuk pada penggunaan tenaga, waktu, sarana/alat, dan dana (Bustami, 2011). Hasil penelitian menunjukkan bahwa Tingkat kesesuaian pada dimensi efisiensi 
yaitu sebesar 94,97\% (>94,16\%), sehingga dapat disimpulkan bahwa dimensi efisiensi dapat memuaskan klien rawat jalan peserta JKN di Puskesmas Indralaya. Penelitian ini tidak sejalan dengan penelitian yang dilakukan oleh (Nugraheni, 2001) dalam penelitiannya didapatkan bahwa dimensi efisiensi belum memuaskan klien JKN, berdasarkan hasil penelitian yang dilakukannya melalui analisa data dengan menggunakan tes kontingensi pada signifikansi 0,05 diperoleh hasil bahwa tidak ada hubungan bermakna antara efisiensi dengan tingkat kepuasan klien.

Responden pada penelitian ini yaitu peserta Jaminan Kesehatan Nasional PBI dan Non PBI, responden pada golongan PBI mengungkapkan bahwa dengan adanya program kesehatan dari pemerintah sangat membantu responden dalam bidang ekonomi (keadaan ekonomi responden lebih baik) dan bisa dengan mudah mengakses pelayanan kesehatan begitu juga menurut responden pada golongan non PBI menyatakan bahwa pelayanan yang mereka dapatkan di Puskesmas Indralaya sudah sebanding dengan premi/iuran yang mereka bayarkan tiap bulannya. Responden mengungkapkan bahwa alasan penilaian tersebut adalah karena responden merasa cocok dan sembuh ketika berobat di Puskesmas tersebut dan mudah mendapatkan akses rujukan ke fasilitas kesehatan sekunder (rumah sakit) jika penyakit yang dialaminya melebihi kapasistas kemampuan penanganan di puskesmas.

\section{Dimensi Efektivitas}

Menurut (Sondakh, Marjati, \& Pipitcahyani, 2014) efektivitas pelayanan kesehatan yang diselenggarakan benar-benar harus sesuai dengan masalah yang ditemukan dan petugas kesehatan harus mengatasinya secara tepat dan benar Hasil penelitian menunjukkan bahwa Tingkat kesesuaian pada dimensi efektivitas yaitu sebesar 93,14\% (<94,16\%), sehingga dapat disimpulkan bahwa dimensi efektivitas belum memuaskan klien rawat jalan peserta JKN di Puskesmas Indralaya. Penelitian ini sejalan dengan penelitian yang dilakukan oleh (Ayuningtiyas, Mustayah, \& Nataliswati, 2013) dalam penelitiannya didapatkan bahwa dimensi efektivitas belum memuaskan klien, berdasarkan hasil penelitian yang dilakukannya melalui angket di tabulasi dan diberi skor (scoring) dari 50 responden hanya 15 responden yang merasa puas terhadap dimensi efektivitas.

\section{Dimensi Reliabilitas}

Menurut (Tjiptono, 2014), dimensi reliabilitas menunjukkan kemampuan perusahaan dalam memberikan pelayanan atau jasa yang diharapkan secara meyakinkan, cepat, akurat, andal, dan konsisten. Hasil penelitian menunjukkan bahwa tingkat kesesuaian pada dimensi reliabilitas yaitu sebesar 93,86\% $(<94,16 \%)$, sehingga dapat disimpulkan bahwa dimensi reliabilitas pada penelitian ini belum memuaskan klien rawat jalan peserta JKN di Puskesmas Indralaya. Hal ini tidak sejalan dengan penelitian yang dilakukan oleh (Fitrianti, Misnaniarti, \& Sitorus, 2012) dalam penelitiannya didapatakan bahwa dimensi reliabilitas dapat memuaskan klien, berdasarkan hasil analisis diketahui 27 orang $(52,9 \%)$ klien Puskesmas Kenten puas terhadap dimensi kehandalan pelayanan yang diberikan.

\section{Dimensi Daya Tanggap}

Daya tanggap merupakan keinginan para petugas kesehatan membantu semua klien serta berkeinginan dan melaksanakan pemberian pelayanan dengan tanggap (Bustami, 2011). Hasil penelitian menunjukkan bahwa Tingkat kesesuaian pada dimensi daya tanggap yaitu sebesar 93,07\% $(<94,16 \%)$, sehingga dapat disimpulkan bahwa dimensi daya tanggap pada penelitian ini belum memuaskan klien rawat jalan peserta JKN di Puskesmas Indralaya. Hal ini tidak sejalan dengan penelitian yang dilakukan oleh (Laeliyah \& Subekti, 2017) dalam penelitiannya didapatkan bahwa dimensi daya tanggap cukup memuaskan klien, berdasarkan hasil penelitian yang dilakukannya dengan uji chi- square yaitu sebanyak $26,1 \%$ responden menyatakan puas pada dimensi daya tanggap, responden menyatakan cukup puas sebanyak $66,3 \%$, dan sebanyak $2,2 \%$ responden menyatakan sangat puas, serta sebanyak $5,4 \%$ responden menyatakan tidak puas. Dilihat dari nilai rerata (mean) yang diperoleh sebesar 3,250 artinya terletak pada interval kelas 2,601-3,400 sehingga termasuk dalam kategori cukup puas.

Pelayanan kesehatan dikatakan memiliki daya tanggap apabila petugas selalu siap sedia untuk membantu klien dengan memberikan informasi yang jelas kepada klien, sistem pelayanan yang tidak berbelit-belit dan cepat tanggap terhadap keluhan klien (Supranto, 2011). 


\section{Dimensi Jaminan}

Jaminan yaitu petugas kesehatan memiliki kompetensi, kesopanan dan dapat dipercaya, bebas dari bahaya, serta bebas dari risiko dan keragu-raguan (Bustami, 2011). Hasil penelitian menunjukkan bahwa tingkat kesesuaian pada dimensi jaminan yaitu sebesar 93,24\% $(<94,16 \%)$, sehingga dapat disimpulkan bahwa dimensi jaminan pada penelitian ini belum memuaskan klien rawat jalan peserta JKN di Puskesmas Indralaya. Artinya dimensi ini dinilai belum mampu memberikan jaminan atau keyakinan klien dalam memperoleh informasi, sebagaimana menurut Kotler bahwa pengetahuan, kepercayaan dan kesopanan pemberi jasa untuk menimbulkan kepercayaan dan keyakinan yang berupa pengetahuan dan kemampuan petugas dalam bekerja, serta jaminan keamanan pelayanan dan kepercayaan terhadap pelayanan akan berdampak pada tingkat kepuasan klien (Kotler, 2001). Pernyataan Kotler sejalan dengan hasil penelitian yang ditemukan oleh (Arnindiah \& Safriantini, 2018) dimana sebesar $(82,5 \%)$ klien merasa puas dengan pelayanan jaminan (Assurance) yang ada di RSI Siti Khadijah Palembang. Kepuasan yang dirasakan klien lebih dominan pada penampilan sikap dokter dan perawat yang ramah terhadap klien dan keluarga klien dan dokter datang sesuai dengan jadwalnya.

\section{Dimensi Empati}

Empati yaitu memberikan perhatian pribadi bagi pelanggan seperti kemudahan dalam hubungan komunikasi, usaha untuk memahami kebutuhan dan keinginan pelanggan (Tjiptono, 2014). Hasil penelitian menunjukkan bahwa Tingkat kesesuaian pada dimensi empati yaitu sebesar $94,79 \% \quad(<94,16 \%)$, sehingga dapat disimpulkan bahwa dimensi empati pada penelitian ini sudah dapat dikatakan memuaskan klien rawat jalan peserta JKN di Puskesmas Indralaya. Penelitian ini sejalan dengan penelitian yang dilakukan oleh (Laeliyah \& Subekti, 2017) didapatkan bahwa dimensi empati cukup memuaskan klien, diperoleh nilai rata-rata (mean) sebesar 3,125 artinya dimensi empati terletak pada interval kelas 2,601-3,400 sehingga pada dimensi ini termasuk dalam kategori cukup puas. Penelitian yang dilakukan oleh (Arnindiah \& Safriantini, 2018) juga mendapatkan hasil dengan $p$-value $=0,000<0,05$ (terdapat hubungan diantara kedua variabel perhatian (empathy) dengan kepuasan klien), dimana hasil nilai PR sebesar 4,342 dengan nilai rentang CI 95\% CI $(2,213-8,520)$.

\section{SIMPULAN}

Berdasarkan hasil penelitian yang telah dilakukan mengenai tingkat kepuasan klien rawat jalan peserta JKN terhadap kualitas pelayanan kesehatan, maka dapat diketahui rata-rata tingkat kepuasan klien perdimensi (rata-rata tingkat kesesuaian) yaitu sebesar 94,16\%. Secara keseluruhan pelayanan rawat jalan klien peserta JKN di Puskesmas Indralaya terdapat 5 (lima) dimensi dari 8 dimensi klien belum merasa puas terhadap pelayanan yang diberikan yaitu dimensi efektivitas (93,14\%), bukti fisik/bukti langsung $(91,93 \%)$, reliabilitas $(93,86 \%)$, daya tanggap $(93,07 \%)$, dan jaminan $(93,24 \%)$. Sedangkan, berdasarkan diagram kartesius pada penelitian ini didapatkan bahwa pada kuadran A terdapat 4 atribut dan menjadi prioritas utama, kemudian pada kuadran B terdapat 12 atribut, dan pada kuadran C terdapat 11 atribut, serta pada kuadran D terdapat 3 atribut.

\section{DAFTAR PUSTAKA}

Ainy, A., Misnaniarti, \& Fajar, N. A. (2012). Importance Performance Analysis on Social Pelayanan Jaminan Sosial Kesehatan di Puskesmas Swakelola Pembina. Jurnal Kesehatan Masyarakat Nasional, 7(No 3), 105-110.

Anggraheni, N. V. (2012). Faktor-Faktor yang Mempengaruhi Pengambilan Keputusan Masyarakat untuk Memilih Jasa Pelayanan Kesehatan di Rumah Sakit PKU Muhammadiyah Simo Kabupaten Boyolali. [Skripsi]. Surakarta: Universitas Muhammadiyah Surakarta.
Arnindiah, N., \& Safriantini, Dian. (2018). Analisis Kepuasan Pasien Rawat Inap Peserta Jaminan Kesehatan Nasional di Rumah Sakit Islam Siti Khadijah Palembang. Jurnal Kesehatan, 11(2).

Ayuningtiyas, K. R., Mustayah, \& Nataliswati, T. (2013). Tingkat Kepuasan Pasien pada Pelayanan Keperawatan di Rumah Sakit. Jurnal Pendidikan Kesehatan, 4(No 2), 83-90.

Basri, A. H., \& Leoganda, D. F. (2016). Hubungan Fasilitas Ruang Rawat Inap dengan Tingkat Kepuasan Pasien BPJS. 
Journals of Ners Community, 07, 47-54.

BPJS Kesehatan. (2015). Sistem Rujukan Berjenjang. Humas BPJS Kesehatan.

BPJS Kesehatan KC Palembang. (2018). Jumlah Kepesertaan JKN di Kabupaten Ogan Ilir Tahun 2017. Palembang.

Bustami. (2011). Penjaminan Mutu Pelayanan Kesehatan dan Akseptabilitasnya. Jakarta: Erlangga.

Dinas Kependudukan dan Pencatatan Sipil Kabupaten Ogan Ilir. (2018). Jumlah Penduduk Kabupaten Ogan Ilir Per Puskesmas Tahun 2017. Indaralaya.

Emilia, S. (2016). Gambaran Tingkat Kepuasan Pasien di UPT Puskesmas Sindangjawa Kabupaten Cirebon. [Skripsi]. Jakarta: Fakultas Ilmu Kesehatan, Universitas Islam Negeri Syarif Hidayatullah Jakarta.

Fitrianti, Misnaniarti, \& Sitorus, R. J. (2012). Perbandingan Kualitas Pelayanan pada Pasien Jamkesmas di Puskesmas Kenten dengan Puskesmas Dempo Palembang. Jurnal Ilmu Kesehatan Masyarakat, 3(November), 260-272.

Jahid, H., Balqis, \& Hamzah, A. (2013). Faktor yang Berhubungan dengan Kepuasan Pasien Peserta Jamkesmas pada Ruang Rawat Inap di Rumah Sakit Elim Rantepao Kabupaten Toraja Utara. [Skripsi]. Makassara: Fakultas Kesehatan Masyarakat, Universitas Hasanuddin. http://repository.unhas.ac.id/bitstream/han dle/123456789/5917/JURNAL fix.pdf?sequence $=1$

Kotler, P. (2001). Prinsip-prinsip Pemasaran. Jakarta: Erlangga.

Laeliyah, N., \& Subekti, H. (2017). Waktu Tunggu Pelayanan Rawat Jalan dengan Kepuasan Pasien Terhadap Pelayanan di Rawat Jalan RSUD Kabupaten Indramayu. Jurnal Kesehatan Vokasional, 1(2), 102112.
Mamik. (2010). Organisasi dan Manajemen Pelayanan Kesehatan Dan Kebidanan. Surabaya: Prins Media Publishing.

Nugraheni, W. (2001). Hubungan Efisiensi Ruang Rawat Inap dengan Tingkat Kepuasan Pasien Rawat Inap di Rumah Sakit Umum Daerah Tidar Magelang pada Bulan Januari Tahun 2001. [Skripsi]. Semarang: Fakultas Kesehatan Masyarakat, Universitas Diponegoro.

Permenkes RI. Peraturan Menteri Kesehatan Republik Indonesia Nomor 75 Tahun 2014 Tentang Pusat Kesehatan Masyarakat (2014). Indonesia.

Perwani, Y. S. (2006). Teori dan Petunjuk Praktek Housekeeping Untuk Akademi Perhotelan: Make Up Room. Jakarta: Gramedia Pustaka Utama.

Pohan, I. S. (2007). Jaminan Mutu Layanan Kesehatan. Jakarta: Penerbit Buku Kedokteran EGC.

Puskesmas Indralaya. (2018). Profil Puskesmas Indralaya Tahun 2018. Indaralaya.

Sondakh, J. J. ., Marjati, \& Pipitcahyani, T. I. (2014). Mutu Pelayanan Kesehatan dan Kebidanan. Jakarta: Salemba Medika.

Sondari, A. (2015). Analisis Kepuasan Pasien Rawat Jalan Peserta Jaminan Kesehatan Nasional (JKN) di Rumah Sakit Umum Daerah (RSUD) Kabupaten Brebes Tahun 2015. [Skripsi]. Semarang: Faklutas Keolahragaan, Universitas Negeri Semarang.

https://lib.unnes.ac.id/22964/1/641141100 9.pdf

Supranto, J. (2011). Pengukuran Tingkat Kepuasan Pelanggan untuk Menaikkan Pangsa Pasar. Yogyakarta: Rineka Cipta.

Tjiptono, F. (2014). Pemasaran Jasa Prinsip, Penerapan, Penelitian. Yogyakarta: Penerbit ANDI. 